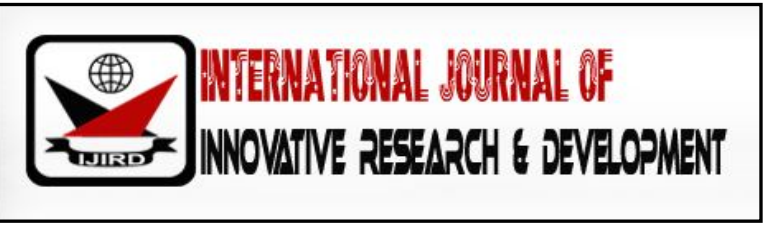

ISSN 2278 - 0211 (Online)

\title{
Evidence of Hypolipidemic and Gastro-Intestinal Histopathological Moderation Effect of Chromolaena Odorata Pretreatmentin Salmonella Typhi Infectedwistar Rats
}

\author{
Isirima, Joshua Charles \\ Lecturer, Department of Biomedical Technology, University of Port Harcourt, Nigeria \\ Siminialayi, Iyeopu Minakiri \\ Professor, Department of Pharmacology, University of Port Harcourt, Nigeria
}

\begin{abstract}
:
Typhoid fever is a disease caused by the human restricted bacterial pathogen Salmonella typhi. This study is aimed at investigating the ability of Chromolaena odorata to prevent the dyslipidemic changes and to evaluate the ability of the plant to reverse the Gastro-intestinal histopathological changes induced by Salmonella typhi in Wistar Rats. One hundred and forty-five (145) animals were divided in to two broad groups, A, with sixty (60) animals and B, with eighty-five (85) animals for pre- and post-treatment studies respectively. Animals in the pre-treatment group were administered graded doses $(100 \mathrm{mg} / \mathrm{kg}, 200 \mathrm{mg} / \mathrm{kg}$ and $400 \mathrm{mg} / \mathrm{kg})$ of methanol leaf extract of Chromolaena odorata for a period of two weeks before they were exposed to a single infective dose of Salmonella typhiinoculum, while animals in the post treatment group, were inoculated with a single infective dose of Salmonella typhi bacteria and were subsequently treated with the graded doses of methanol leaf extract of Chromolaena odorata and $500 \mathrm{mg} / 70 \mathrm{~kg}$ dose of ciprofloxacin for a period of fifteen days, when the animals were confirmed infected. The rats were humanely sacrificed using diethyl ether as anesthesia and blood was collected from the pretreatment group for lipid profile analysis, while intestinal tissues were collected from the posttreatment group for histopathological examination. Chromolaena odoratapre-treatment prevented the usual dyslipidemia associated with Salmonella typhi infection, while post-treatment reversed the adverse histopathological changes induced by Salmonella typhi in the animals in a dose dependent manner.
\end{abstract}

Keywords: Chromolaena odorata, hypolipidemia, gastro-intestinal histopathology, Salmonella typhi, Wistar Rats

\section{Introduction}

Studies on the hypoglycemic effects of ethanol leaf extract of Chromolaena odorata carried out by Ijeoma, et al., (2014), revealed that this plant extract significantly reduces the serum total cholesterol, LDL-cholesterol and triacylglycerol and significantly increase HDL-cholesterol, depicting a hypo-lipidaemic, as well as cardio-protective effect of the extract against degenerative diseases. This according to a report by Nwanjo, et al., (2007), was attributed to the presence of saponin fractions. Other studies have also remarked that the lowering of blood cholesterol is associated with the presence of saponins and flavonoids (Ikeyi, et al., 2013) which are reported to be found in Chromolaena odorata extract (Prasad, et al., 2005). In a study to evaluate the acute toxicity in mice and subchronic toxicity of hydroethanolic extract of Chromolaena odorata in rats Ogbonnia et al., (2010) also reported a decrease in the plasma total cholesterol (TC), triglyceride (TG) and LDL-cholesterol levels as well as an increase HDL-cholesterol levels. In a study to evaluate the serum liver enzyme markers, lipid profile and kidney function parameters, in typhoid patients, Omeh, et al., (2015), reported a significant increase in the concentration of ALT, AST and ALP as well as LDL-Cholesterol, triglycerols, VLDL and a decrease in HDL concentration in typhoid patients when compared with normal individuals and a significant decrease in the concentrations of globulin, total protein and albumin in the test group when compared with the control group. In another study to investigate the effect of salmonella on tissue lipids, Solomon, et al., (2012) reported that Salmonella infection caused dyslipidemia in rats characterized by enhanced hypertriglyceridemia, cholesterogenesis, and phospholipidosis in plasma, low density lipoprotein-very low-density lipoprotein (LDL-VLDL) in erythrocytes and organs as well as an increase in the concentrations of free fatty acids (FFA) in plasma and erythrocytes.In a study to investigate the Intestinal histopathology of mice infected with Salmonella typhimurium, Zainab (2012), reported hyperplasia of goblet cells as well as infiltration of inflammatory cells in the lamina propria of atrophic villi. He also reported that observation of the tissues with electron microscope revealed that S. typhimurium lay close to the brush 
border of the villi of ileum of the infected mice and observed a degeneration of the brush border and the apical cytoplasm with cavity formation occurring near a bacterium in another section of the tissue. His study also revealed in addition, swelling, budding and elongation of microvilli. Our study therefore intends to investigate the ability of Chromolaena odrata to prevent the dyslipidemic effect as well as to reverse the Gastro-intestinal histopathological changes associated with Salmonella typhi infection.

\section{Methods}

\subsection{Collection of Samples}

Leaves of Chromolaena odorata were fetched from Omuoko- Aluu community and cleaned of soil and dust by washing with tap water. The leaves were identified at the Department of Plant Science and Biotechnology, University of Pot Harcourt, by Dr. Ekeke Chimezie with the herbarium number UPH/ V/ 1234.

\subsection{Plant Extraction}

After collection, the leaves of the plant were shade-dried at room temperature (32-35을 to a constant weight over a period of seven (7) days. A little modification of the cold maceration extraction method as described by Hanan et al., (2013), was employed. Fifty grams of powdered leaves of Chromolaena odorata was dissolved in $1000 \mathrm{ml}$ of seventy percent methanol in a 2 litres conical flask, shaken vigorously at 1-hour intervals, for a period of 12 hours and then left to stand over-night at room temperature for effective extraction. This was filtered by using a 0.45 millipore filter paper. The clear solution obtained was then concentrated with a rotary evaporator at $40^{\circ} \mathrm{C}$ and $200 \mathrm{rpm}$ and subsequently, on a steam bath at $40^{\circ} \mathrm{C}$. The semisolid extract obtained was stored in sterile pre-weighed screw capped bottles and labeled accordingly. The extracts were stored in desiccators at room temperature until when needed.

\subsection{Isolation and Culturing the Organisms}

All media used in this study were prepared following the manufacturer's instruction. Salmonella typhi was isolated from typhoid patients in "University of Port Harcourt Teaching Hospital (UPTH)" Rivers State. Bile salt broth (broth culture) (Watson, 1954) and streptokinase broth (clot culture) (Watson, 1978) were used for enrichment. The enriched samples showing visible turbidity were streaked on Mac-Conkey agar media. The isolates producing characteristic colonies were identified by conventional biochemical tests.

\subsection{Experimental Design}

One hundred and forty-five (145) animals were divided in to two broad groups A with sixty animals (60) and B with eighty-five (85) animals for pre-treatment and post-treatment studies respectively.

\subsection{Pre-Treatment Group}

Sixty animals where sub-divided into three groups, (A1,A2 and A3) of twenty (20) animals each and were pre-treated with the methanol leaf extract of Chromolena odorata for 14 days to assess whether the plant extract will protect the apparently healthy animals from Salmonella typhi infection by checking the effect on lipid profile. The animals were pretreated with low $(100 \mathrm{mg} / \mathrm{kg})$, medium $(200 \mathrm{mg} / \mathrm{kg})$ and high $(400 \mathrm{mg} / \mathrm{kg})$ doses of the methanol leaf extract of Chromolena odoratain addition to their normal feed (Grower's mash) for fourteen days. At the end of fourteen days pre-treatment period, fifteen animals, five from each group were randomly taken and humanely sacrificed and blood was collected and immediately transferred into appropriately labelled sample bottles containing anticoagulant for lipid profile analysis (this is day 0 in the tables). The remaining 45 animals were challenged with the infective dose $\left(2.0 \times 10^{8} \mathrm{cfu} / \mathrm{ml}\right)$ of Salmonella typhi and observed for signs of infection. At five days intervals, and at the end of the fifteenth day, 5 animals from each group were humanely sacrificed using diethyl ether anesthesia and blood was collected for lipid profile assay.

\subsection{Post-Treatment}

Eighty-five (85) animals were divided into 6 groups (1-6). Group 1 (normal) had five (5) animals; Group 2 (negative control) had twenty (20) animals, while groups 3-6 each had fifteen (15) animals. Group 1 animals were not treated throughout the experiment but were given free access to normal animal feed and water ad libitum. Group 2 contained Salmonella typhi-infected rats not treated after disease induction. Group 3 contained Salmonella typhi-infected rats treated with $100 \mathrm{mg} / \mathrm{kg}$ (low dose) of MLECO. Group 4 contained Salmonella typhi-infected rats treated with 200mg/ kg (medium dose) of methanol leaf extract of Chromolena odorata. Group 5 contained Salmonella typhi-infected rats treated with $400 \mathrm{mg} / \mathrm{kg}$ (high dose) of methanol leaf extract of Chromolena odorata. Group 6 contained Salmonella typhi-infected rats treated with $500 \mathrm{mg} / 70 \mathrm{~kg}$ of a standard antibiotic drug (Ciprofloxacin). Eighty (80) animals (groups 2-6) were orogastrically challenged with an infective dose $\left(2.0 \times 10^{8} \mathrm{cfu} / \mathrm{ml}\right)$ of Salmonella typhi. After infection had set in (through observation of signs like weakness, anorexia, non-productive cough, watery stool, standing of the hairs as in cold condition and isolation of the organism from the stool of the infected animals), five animals were humanely sacrificed using diethyl ether anesthesia and intestinal tissues were collected for preliminary screening (day 0),while the rest 75 animals were treated with the methanol 
leaf extract of Chromolena odorata according to the different doses of the sub-group and the standard antibiotic (Ciprofloxacin), once daily, for fifteen days. After five days interval of treatment and on the sixteenth day, 5 animals from each group were again humanely sacrificed and intestinal tissue collected aseptically for histopathological examination.

\subsection{Preparation of the Extract Concentrations and Antibiotic}

Stock solutions for the extract were prepared by dissolving $500 \mathrm{mg}$ in $1 \mathrm{ml}$ of dimethylsulfoxide (DMSO). An antibiotic control was made by dissolving 500mg of Ciprofloxacin in sterile distilled water. DMSO was also used as vehicle control in the study.

\subsection{Lipid Profile Analysis}

Cholesterol and High-Density Lipoprotein-Cholesterol (HDL) determination were carried out using Randox automated method and the method of Lothar (1998), while Triglycerides (Trigs) determination was carried out using Randox automated method and the method of Tietz (1990).

\subsection{Histopathology Studies}

The animals were anaesthetized with diethyl ether, dissected aseptically to remove the Intestine which was then transferred into $10 \%$ chloroform and later trimmed down to a size of $2 \mathrm{~mm}$ to $4 \mathrm{~mm}$ thickness, to allow the fixative to readily penetrate the tissue. The tissues were exposed to different stages of processing by standard method as described by (Baker, 1945) including, fixation, dehydration, clearing, impregnation, embedding, sectioning and staining with hematoxylin and eosin (H\&E) and finally mounting.

\subsection{Statistical Analysis}

The results are presented as Mean \pm Standard error of mean. Differences between means were assessed using Analysis of variance (ANOVA) and posttest using LSD multiple comparison test (Mead, \& Curnow, 1982).

\section{Results}

\subsection{Effect of Methanol Leaf Extract of Chromolaena Odorata Pre-Treatment on Lipid Profile in Salmonella Typhi Infected Wistar} Rats

The consequential pre-treatment effect of methanol leaf extract of Chromolaena odoratais a significant increase $(\mathrm{p}<0.05)$ in high density lipoprotein cholesterol (HDL), and an insignificant decrease in low density lipoprotein cholesterol (LDL), triglycerides and cholesterol levels when compared with the normal, While pre-treatment resulted in the observed effects, inoculation of the animals subsequent to the pre-treatment resulted in the opposite effect, causing a slow and an insignificant decrease in $\mathrm{HDL}$ (table 1)as well as an insignificant increase in LDL, triglycerides and cholesterol as presented in tables 2, 3 and 4. ANOVA comparison, showed a significant difference between the negative control and normal group and between the negative control and all treatment groups on days 0, 6, 11 and 16 in HDL, LDL and triglycerides.

\subsection{Effect of Methanol Leaf Extract of Chromolaena Odorata Treatment on Intestinal Histology in Salmonella Typhi Infected} Wistar Rats

Histological examination of the section of small intestine of normal control group showed normal epithelial lining that is typically of the columnar variety, while those of the infected group showed intensely disrupted tissues. In animals treated with $100 \mathrm{mg} / \mathrm{kg}$ of the extract for five days, the small intestine showed highly infected villi, while in animals treated with $200 \mathrm{mg} / \mathrm{kg}$ for 5 days showed sloughing of the lining and poorly organized villi as well as proliferation of gut associated lymphatic tissue cells. On the contrary the small intestine of rat infected with S. typhi and treated with $400 \mathrm{mg} / \mathrm{kg}$ of C. odorata for 5 days, showed intact duodenal glands and normal tissue architecture. The small intestines of rat infected with S. typhi and treated with $500 \mathrm{mg} / 70 \mathrm{gk}$ of ciprofloxacin showed that the small intestinal tissue was replete with transverse sections of the numerous microvilli that are highly basophilic. Photomicrograph of the small intestine of rat infected with S. typhi and treated with $100 \mathrm{mg} / \mathrm{kg}$ of C. odorata for 10 days, showed infected villi, while those infected with S. typhi and treated with $200 \mathrm{mg} / \mathrm{kg}$ of C. odorata for 10 days, showed normal epithelial lining. Similarly, the small intestine of rat infected with S. typhi and treated with $400 \mathrm{mg} / \mathrm{kg}$ of C. odorata and $500 \mathrm{mg} / 70 \mathrm{~kg}$ of ciprofloxacin for 10 days, showed normal tissues architecture. Histological examination of the small intestine of rat infected with S. typhi and treated with $100 \mathrm{mg} / \mathrm{kg}$ of C. odorata for 15 days showed infection, while the small intestine of rat infected with S. typhi treated with $200 \mathrm{mg} / \mathrm{kg}, 400 \mathrm{mg} / \mathrm{kg}$ of C. odorata and $500 \mathrm{mg} / \mathrm{kg}$ of ciprofloxacin for 15 days, showed normal tissue architecture. 


\begin{tabular}{|c|c|c|c|c|}
\hline Group & Day 0 & Day 6 & Day 11 & Day 16 \\
\hline Normal & $5.40 \pm 0.36$ & $5.40 \pm 0.53$ & $5.40 \pm 0.55$ & $5.40 \pm 0.35$ \\
\hline N. Control & $2.13 \pm 0.20^{* *}$ & $2.10 \pm 0.15^{* *}$ & $1.90 \pm 0.21 * *$ & $2.07 \pm 0.24^{* *}$ \\
\hline Low Dose & $* 9.43 \pm 0.18^{* * *}$ & $* 8.87 \pm 0.15^{* * *}$ & $* 7.60 \pm 0.21 * * *$ & $* 6.83 \pm 0.23^{* * *}$ \\
\hline Medium Dose & $* 11.07 \pm 0.43^{* * *}$ & $* 9.30 \pm 0.32^{* * *}$ & $* 8.33 \pm 0.28^{* * *}$ & $* 7.47 \pm 0.29 * * *$ \\
\hline High Dose & $* 19.37 \pm 0.23^{* * *}$ & $* 16.43 \pm 0.26^{* * *}$ & $* 12.87 \pm 0.20^{* * *}$ & $* 9.60 \pm 0.32^{* * *}$ \\
\hline
\end{tabular}

Table 1: Effect of Methanol Leaf Extract of Chromolaena Odorata Pre-Treatment on

High Density Lipoprotein Cholesterol [HDL (Mmol/ L)] in Salmonella Typhi Infected Wistar Rats

Significant Difference between Normal and Test Groups

Significant Difference between Normal and Negative Control

Significant Difference Between and Negative Control and Test Groups

- Normal (Animals not exposed to any form of treatment but were fed ad libitum)

- Negative Control (Animals inoculated with Salmonella typhi without treatment)

- Low Dose (100mg/ kg of extract)

- Medium Dose (200mg/ kg of extract)

- High Dose $(400 \mathrm{mg} / \mathrm{kg}$ of extract)

\begin{tabular}{|c|c|c|c|c|}
\hline Group & Day 0 & Day 6 & Day 11 & Day 16 \\
\hline Control & $7.40 \pm 037$ & $7.41 \pm 0.88$ & $7.40 \pm 0.62$ & $7.40 \pm 0.82$ \\
\hline Neg. Control & $18.83 \pm 1.48^{* *}$ & $23.50 \pm 0.74^{* *}$ & $24.27 \pm 0.73^{* *}$ & $21.33 \pm 0.38^{* *}$ \\
\hline Low Dose & $7.27 \pm 0.41^{* * *}$ & $7.33 \pm 0.47 * * *$ & $7.40 \pm 0.42^{* * *}$ & $7.50 \pm 0.45^{* * *}$ \\
\hline Medium Dose & $7.17 \pm 0.12^{* * *}$ & $7.23 \pm 0.09^{* * *}$ & $7.33 \pm 0.38^{* * *}$ & $7.43 \pm 0.35^{* * *}$ \\
\hline High Dose & $7.10 \pm 0.06^{* * *}$ & $7.23 \pm 0.49^{* * *}$ & $7.30 \pm 0.17^{* * *}$ & $7.37 \pm 0.09^{* * *}$ \\
\hline
\end{tabular}

Table 2: Effect of Methanol Leaf Extract of Chromolaena Odorata Pre-Treatment on Low Density Lipoprotein Cholesterol [LDL (Mmol/ L)] In Salmonella Typhi Infected Wistar Rats

\begin{tabular}{|c|c|c|c|c|}
\hline Group & Day 0 & Day 6 & Day 11 & Day 11 \\
\hline Control & $36.67 \pm 11.39$ & $36.67 \pm 11.39$ & $36.67 \pm 11.39$ & $36.67 \pm 11.39$ \\
\hline Neg. Control & $79.67 \pm 9.70^{* *}$ & $83.00 \pm 9.64^{* *}$ & $87.67 \pm 5.55^{* *}$ & $92.00 \pm 9.71^{* *}$ \\
\hline Low Dose & $28.67 \pm 4.10^{* * *}$ & $32.33 \pm 1.76^{* * *}$ & $35.33 \pm 3.28^{* * *}$ & $38.00 \pm 9.50^{* * *}$ \\
\hline Medium Dose & $26.33 \pm 4.67^{* * *}$ & $28.67 \pm 4.10^{* * *}$ & $32.33 \pm 1.76^{* * *}$ & $35.67 \pm 2.96^{* * *}$ \\
\hline High Dose & $21.67 \pm 1.76^{* * *}$ & $25.67 \pm 4.81^{* * *}$ & $28.33 \pm 4.06^{* * *}$ & $32.33 \pm 4.26^{* * *}$ \\
\hline
\end{tabular}

Table 3: Effect of Methanol Leaf Extract of Chromolaena Odorata Pre-Treatment on

Triglycerides (Mmol/ L) in Salmonella Typhi Infectedwistar Rats

\begin{tabular}{|c|c|c|c|c|}
\hline Group & Day 0 & Day 6 & Day 11 & Day 16 \\
\hline Control & $51.00 \pm 16.20$ & $51.00 \pm 16.20$ & $51.00 \pm 16.20$ & $51.00 \pm 16.20$ \\
\hline Neg. Control & $65.33 \pm 7.42$ & $67.33 \pm 6.74$ & $70.00 \pm 9.29$ & $72.00 \pm 8.14$ \\
\hline Low Dose & $42.00 \pm 7.00$ & $44.67 \pm 6.23$ & $47.67 \pm 6.69$ & $47.67 \pm 5.36$ \\
\hline Medium Dose & $40.33 \pm 10.35$ & $40.67 \pm 7.31$ & $44.00 \pm 5.13$ & $45.67 \pm 4.70$ \\
\hline High Dose & $36.00 \pm 5.86$ & $39.00 \pm 9.02$ & $41.67 \pm 6.69$ & $44.67 \pm 4.98$ \\
\hline
\end{tabular}

Table 4: Effect of Methanol Leaf Extract of Chromolaena Odorata Pre-Treatment on

Cholesterol (Mmol/ L) in Salmonella Typhi Infected Wistar Rats 


\subsection{Histological Plates of the Intestines}

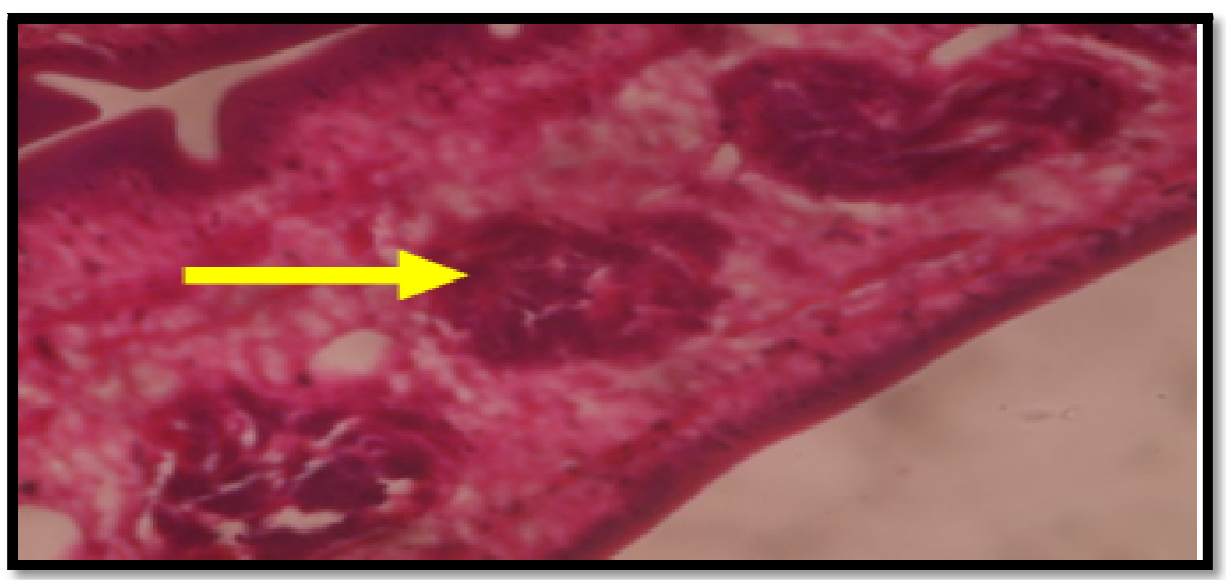

Figure 1: Photomicrograph of Section of Small Intestine of Normal Rat, the Epithelial Lining Is Typically of the Columnar Variety (Normal Day- 6)

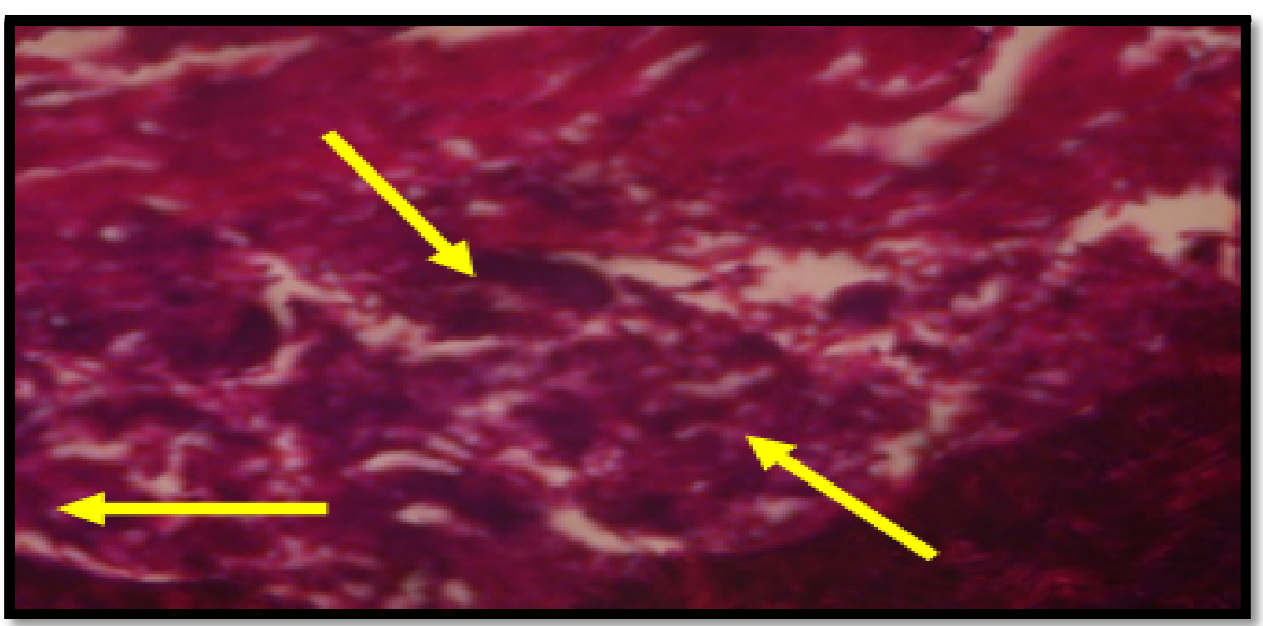

Figure 2: Photomicrograph of the Small Intestine of Rat Infected with S. Typhi, the Tissues Are Intensely Disrupted (Negative Control Day-6)

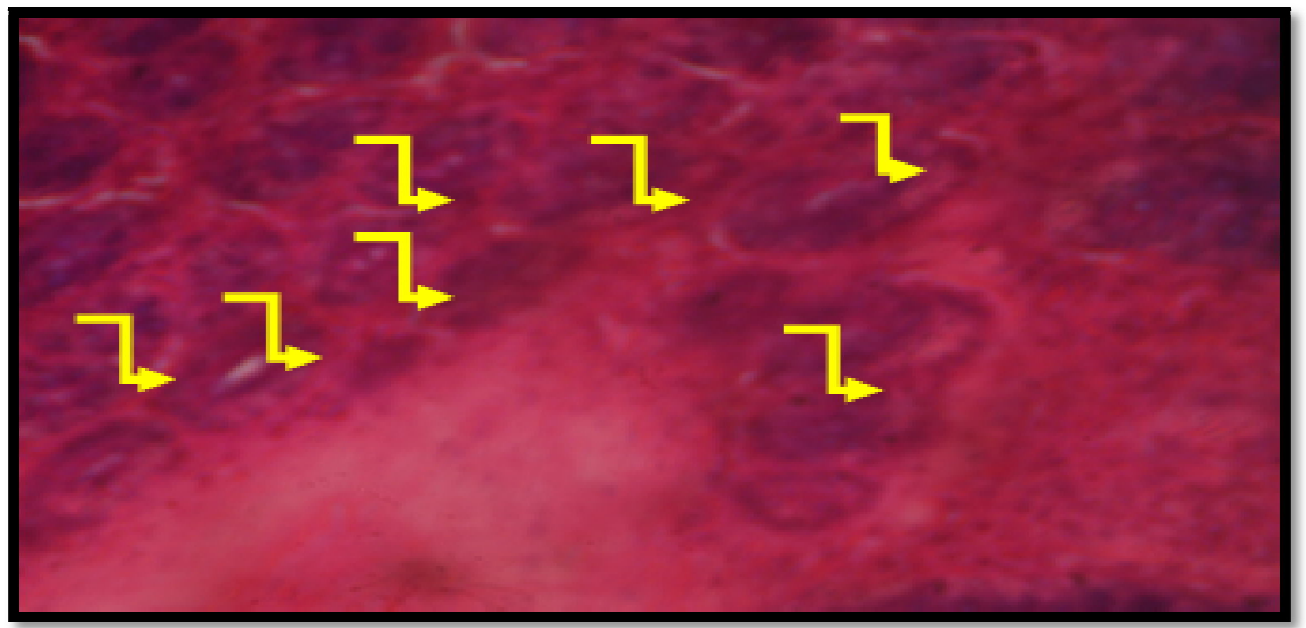

Figure 3: Photograph of the Small Intestines of Rat Infected with S. Typhi Showing That the Small Intestinal Tissue Was Replete with Transverse Sections of the Numerous Microvilli That Are Highly Basophilic (Positive Control) 


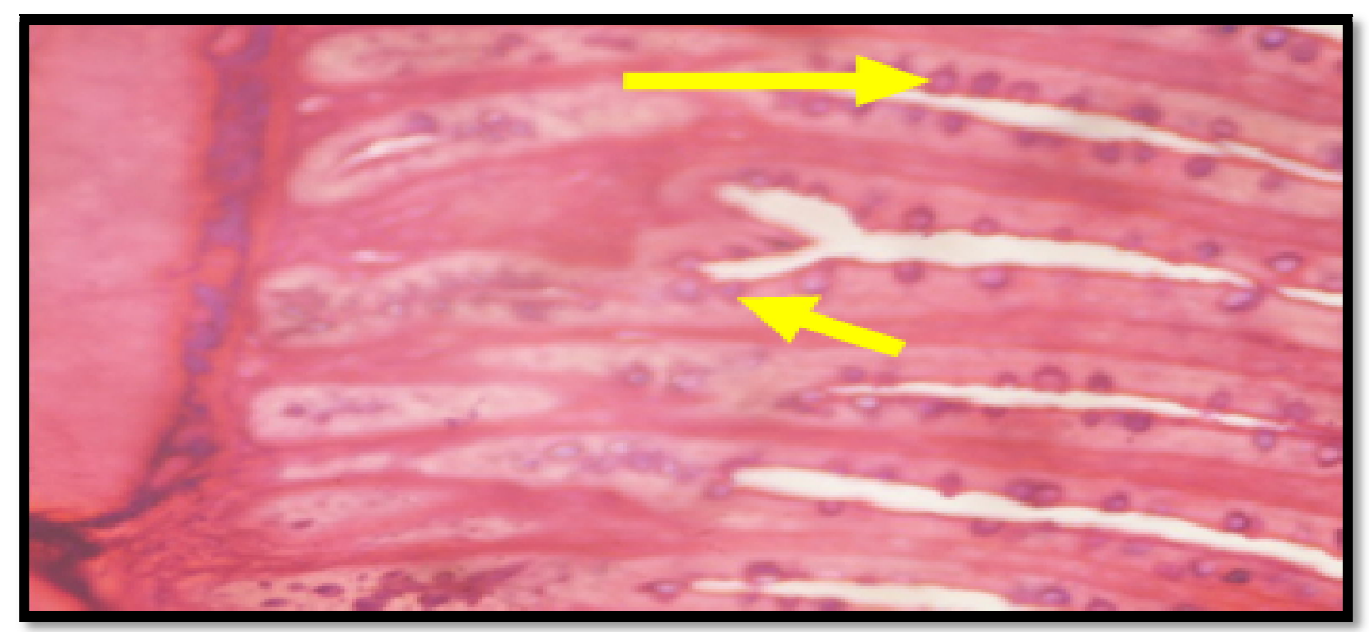

Figure 4: Photomicrograph of the Small Intestine of Rat Infected with

S. Typhi and Treated with 100mg/ Kg of C. Odorata for 6 Days, Showing Highly Infected Villi

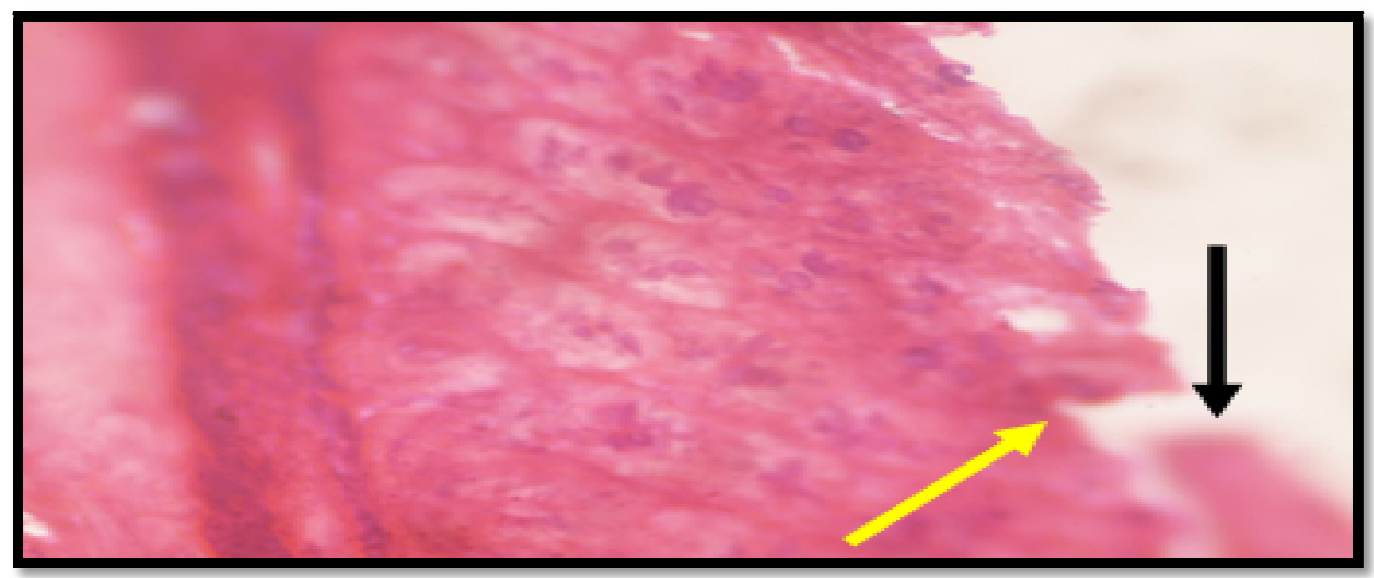

Figure 5: Photomicrograph of the Small Intestine of Rat Infected With S. Typhi and

Treated With 200mg/ Kg of C. Odorata for 6 Days Showing Sloughing of the

Lining and Poorly Organized Villi as Well as Proliferation of Gut Associated Lymphatic Tissue Cells

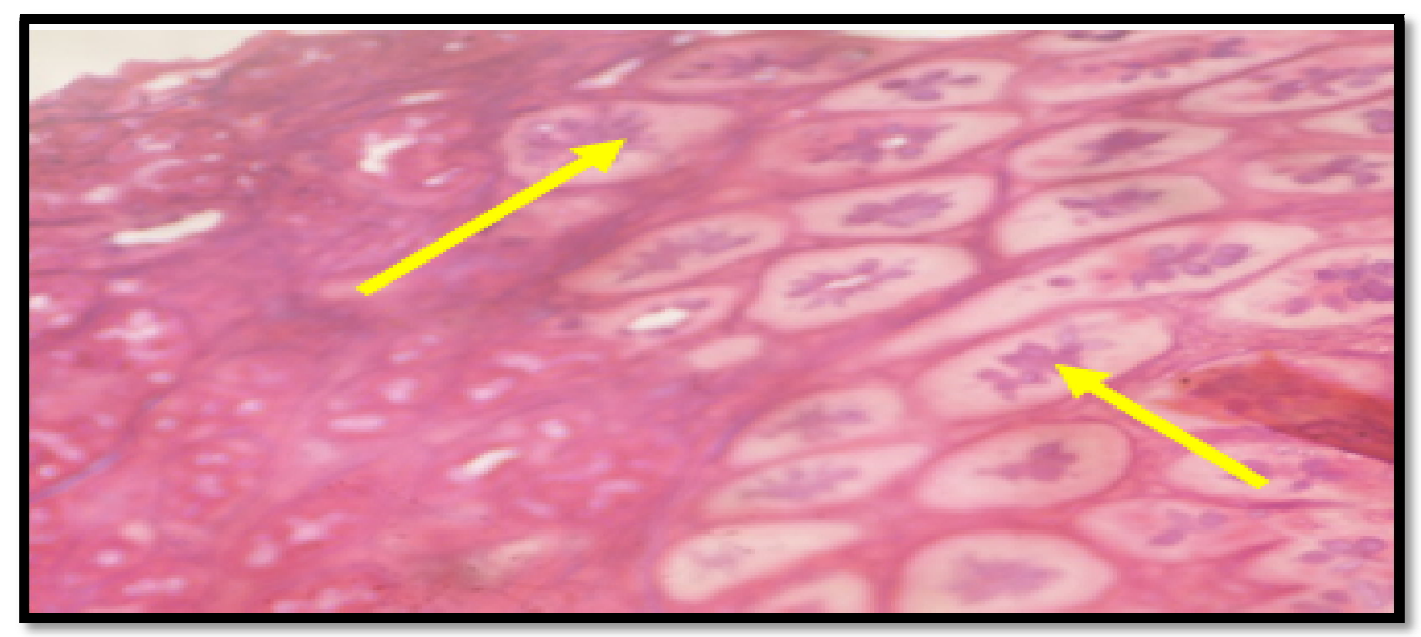

Figure 6: Photomicrograph of the Small Intestine of Rat Infected With S. Typhi and Treated with $400 \mathrm{mg} / \mathrm{Kg}$ of C. Odorata for 6 Days, Showing Intact Duodenal Glands and Normal Tissue Architecture 


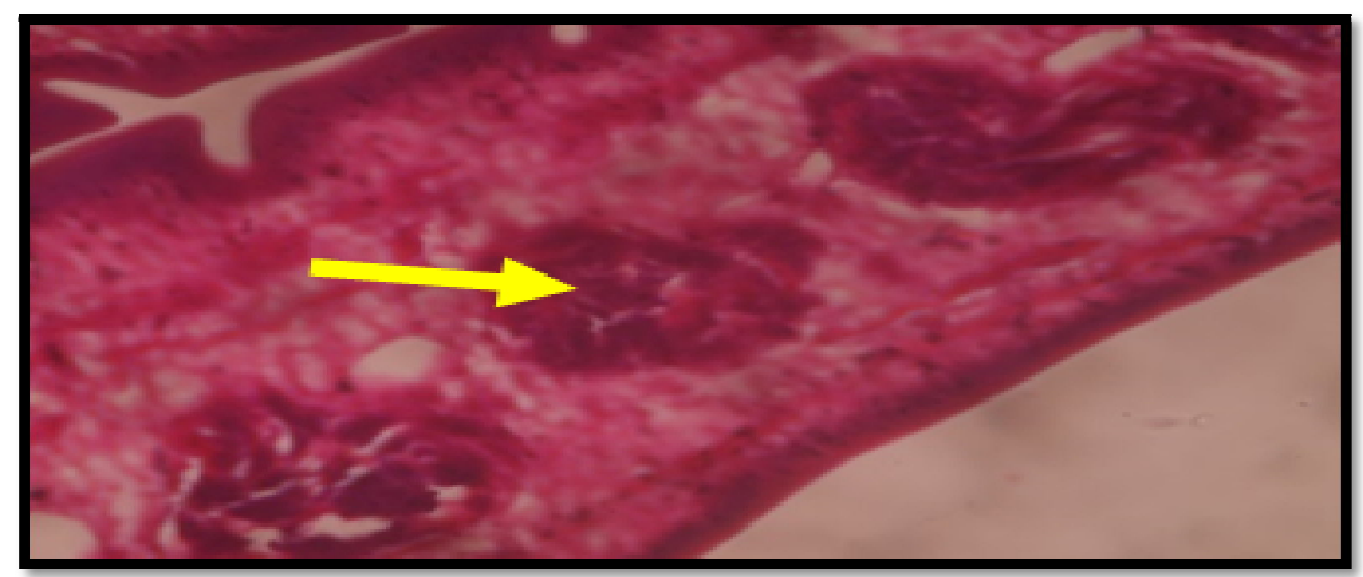

Figure 7: Photomicrograph of Section of Small Intestine of Normal Rat, the Epithelial Lining Is Typically of the Columnar Variety (Normal Day- 11)

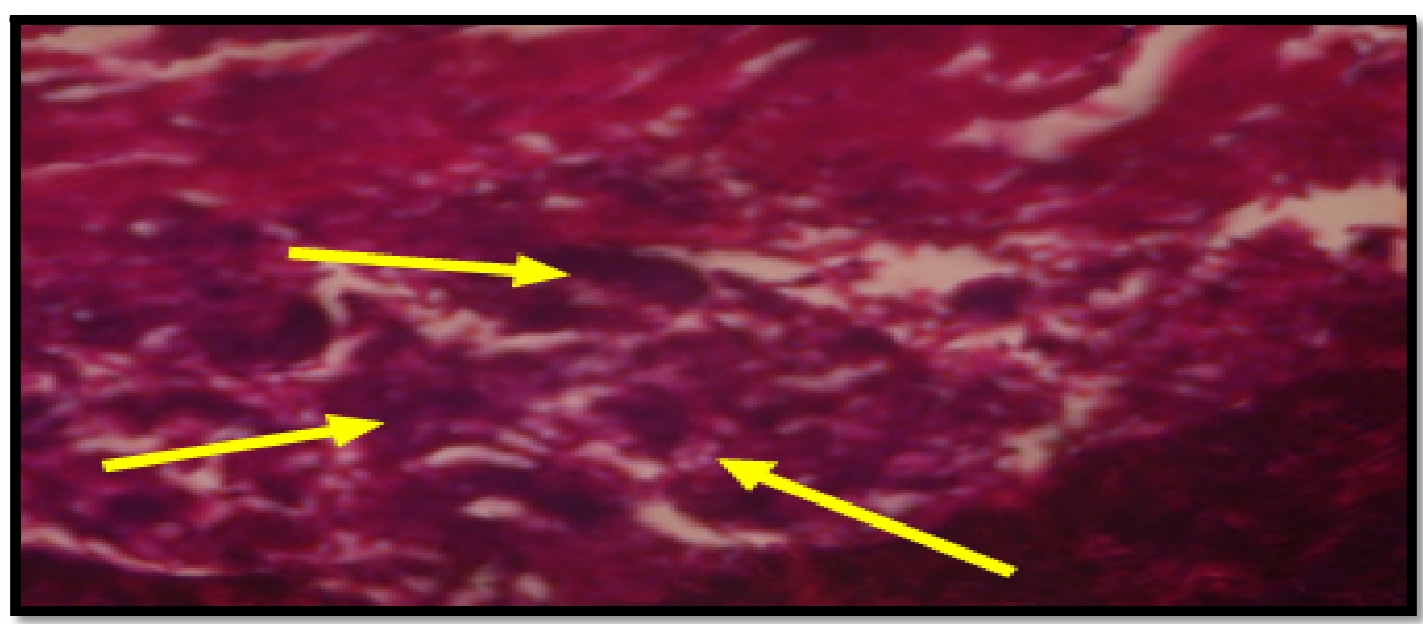

Figure 8: Photomicrograph of the Small Intestine of Rat Infected with S. Typhi, the Tissues Are Intensely Disrupted (Day-11)

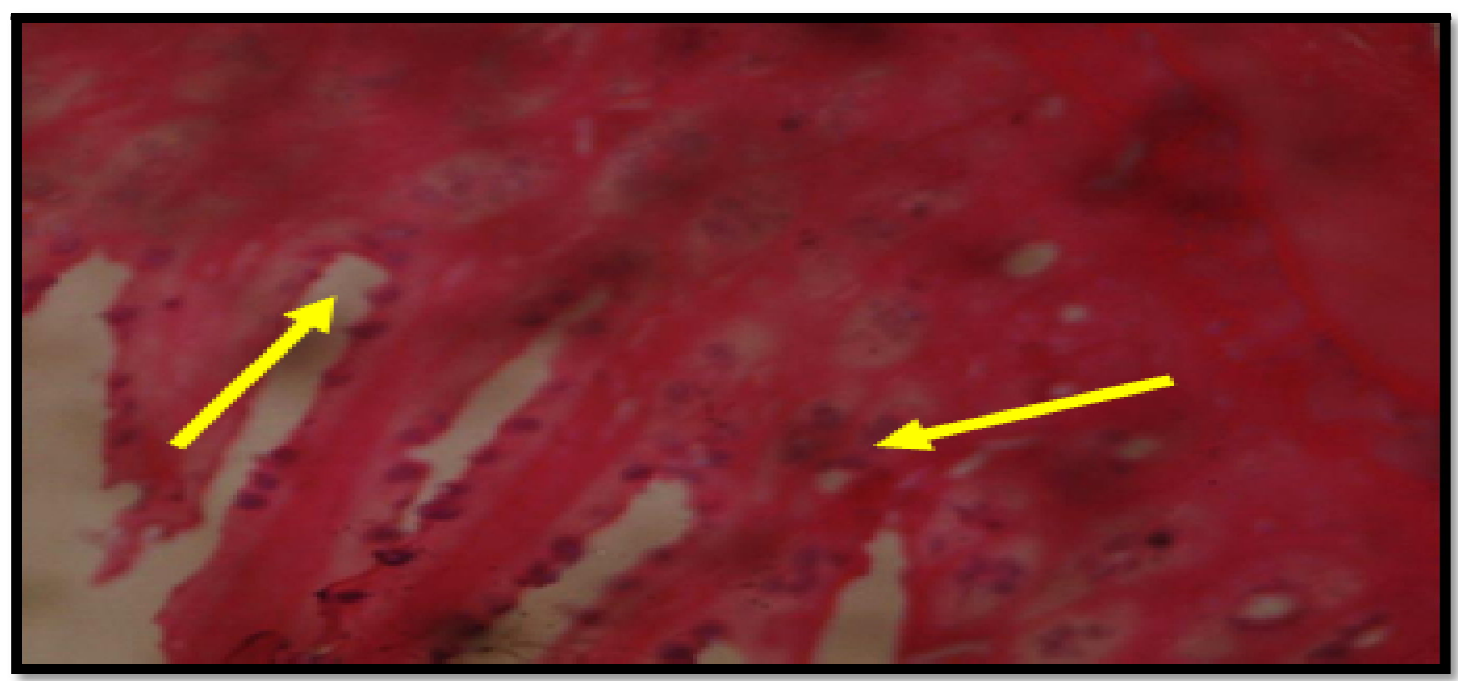

Figure 9: Photomicrograph of the Small Intestine of Rat Infected with S. Typhi and Treated with $500 \mathrm{mg} / \mathrm{Kg}$ of Ciprofloxacin for 10 Days Showing Intact Duodenal Glands and Normal Tissue Architecture 


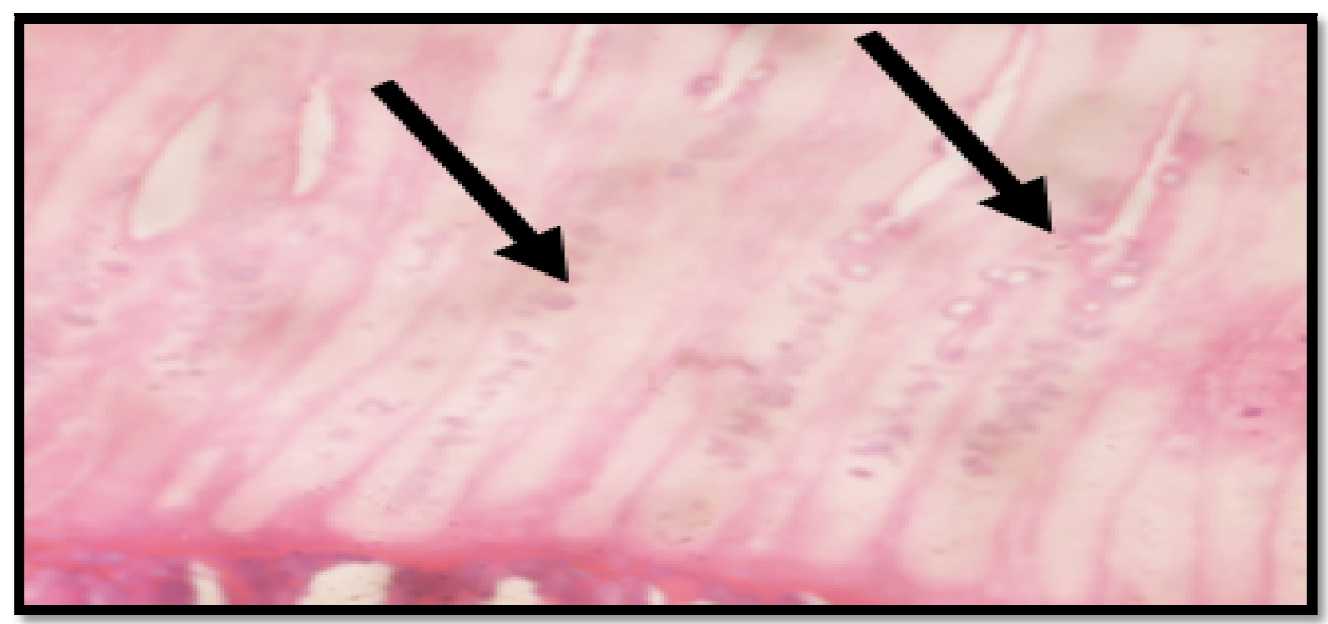

Figure 10: Photomicrograph of the Small Intestine of Rat Infected With S. Typhi and Treated with $100 \mathrm{mg} / \mathrm{Kg}$ of C. Odorata for 10 Days, Showing Infected Villi

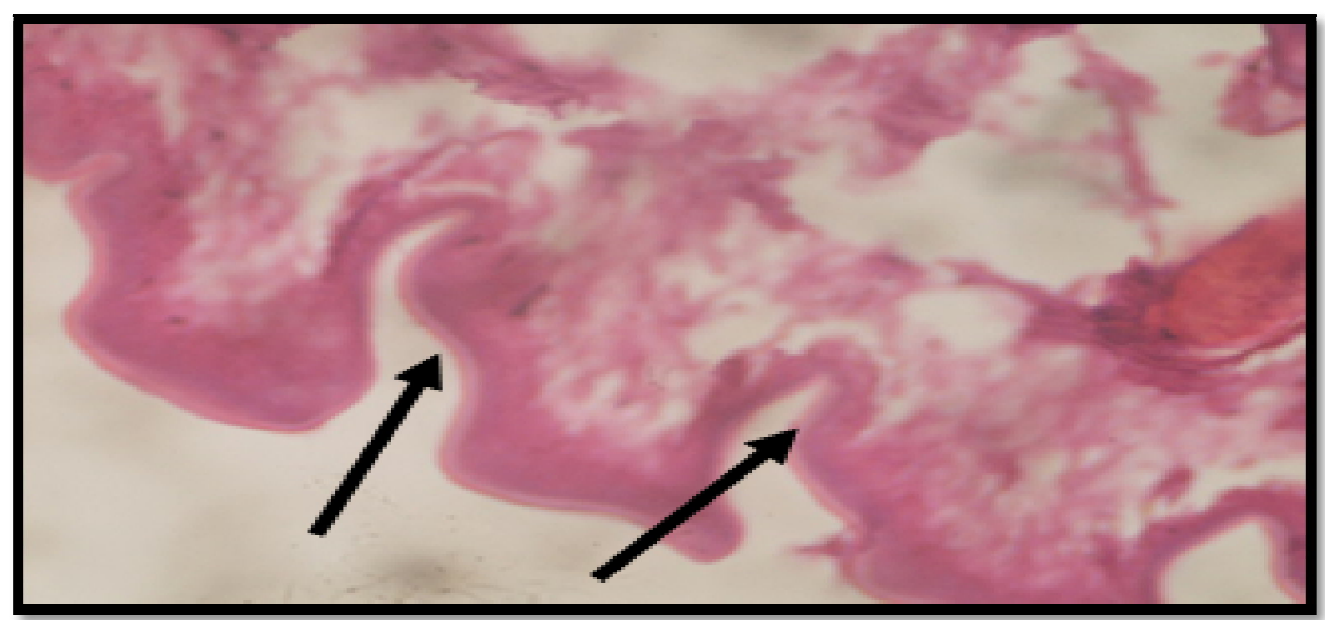

Figure 11: Photomicrograph of the Small Intestine of Rat Infected with S. Typhi and Treated with 200mg/ Kg of C. Odorata for 10 Days, Showing Normal Epithelial Lining

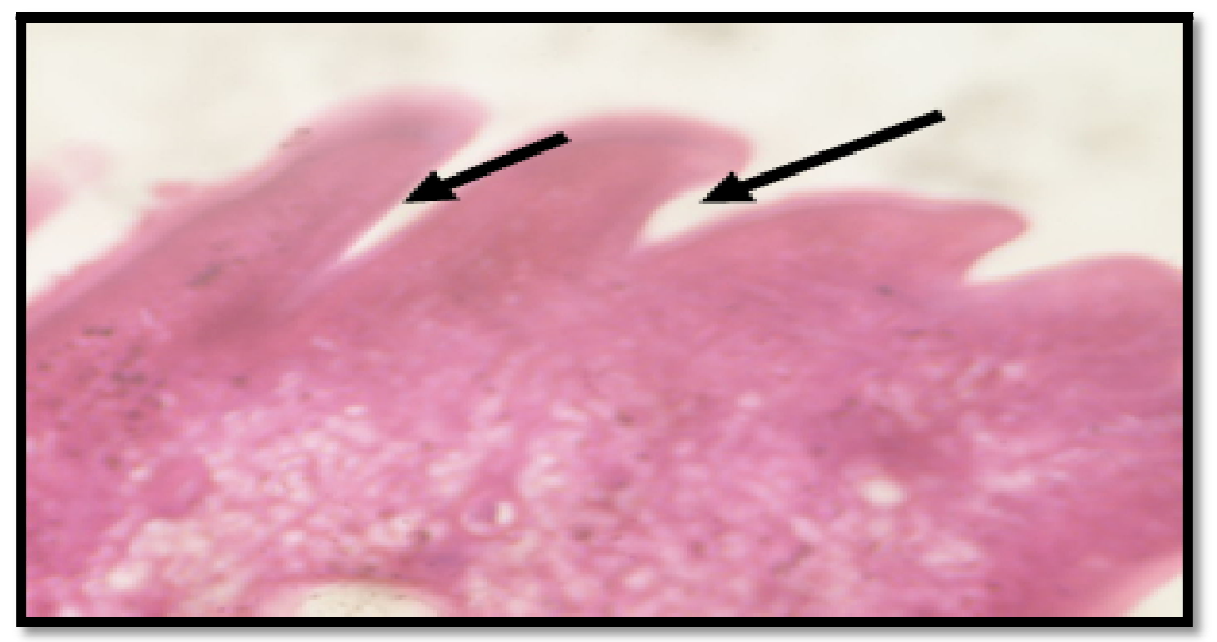

Figure 12: Photomicrograph of the Small Intestine of Rat Infected with S. Typhi and Treated with 400mg/ Kg of C. Odorata for 10 Days, Showing Normal Tissues 


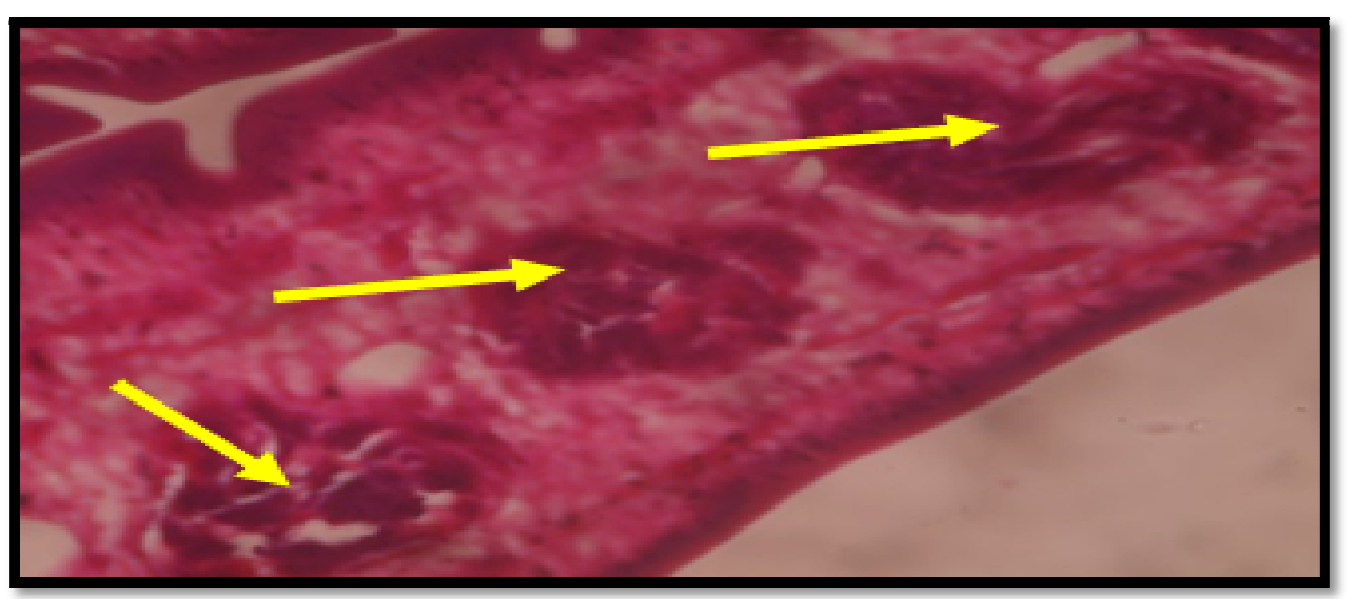

Figure 13: Photomicrograph of Section of Small Intestine of Normal Rat, the Epithelial Lining Is Typically $\mathrm{f}$ the Columnar Variety (Normal Day- 16)

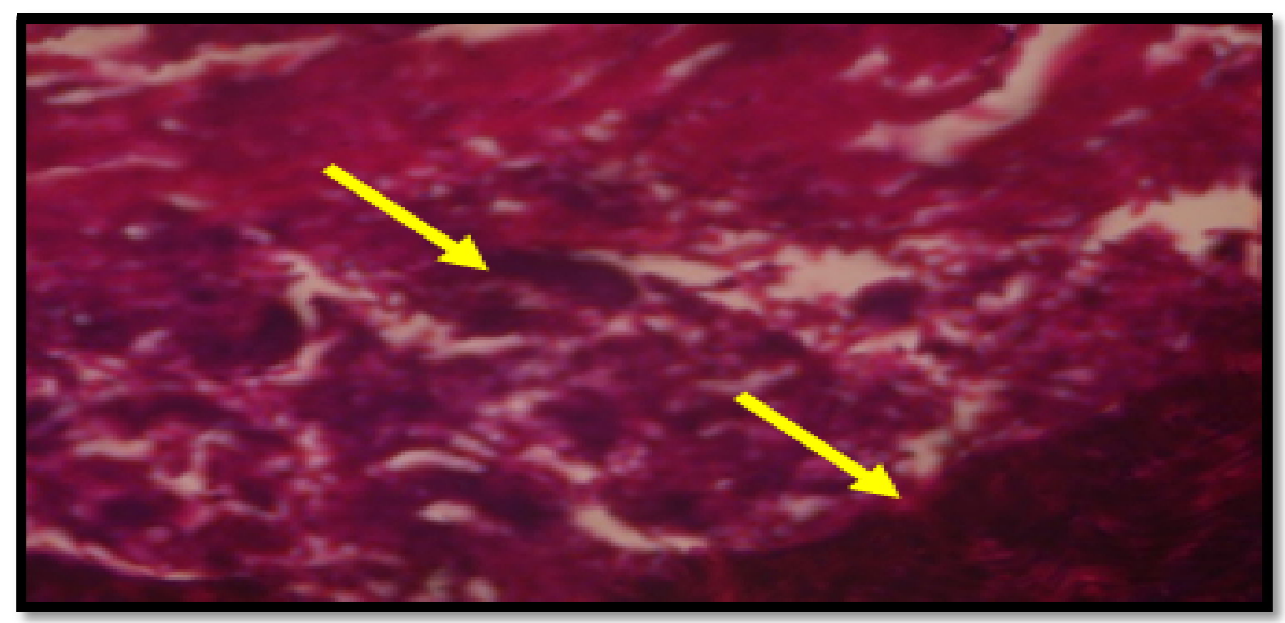

Figure 14: Photomicrograph of the Small Intestine of Rat Infected with S. Typhi, the Tissues Are Intensely Disrupted (Day-16)

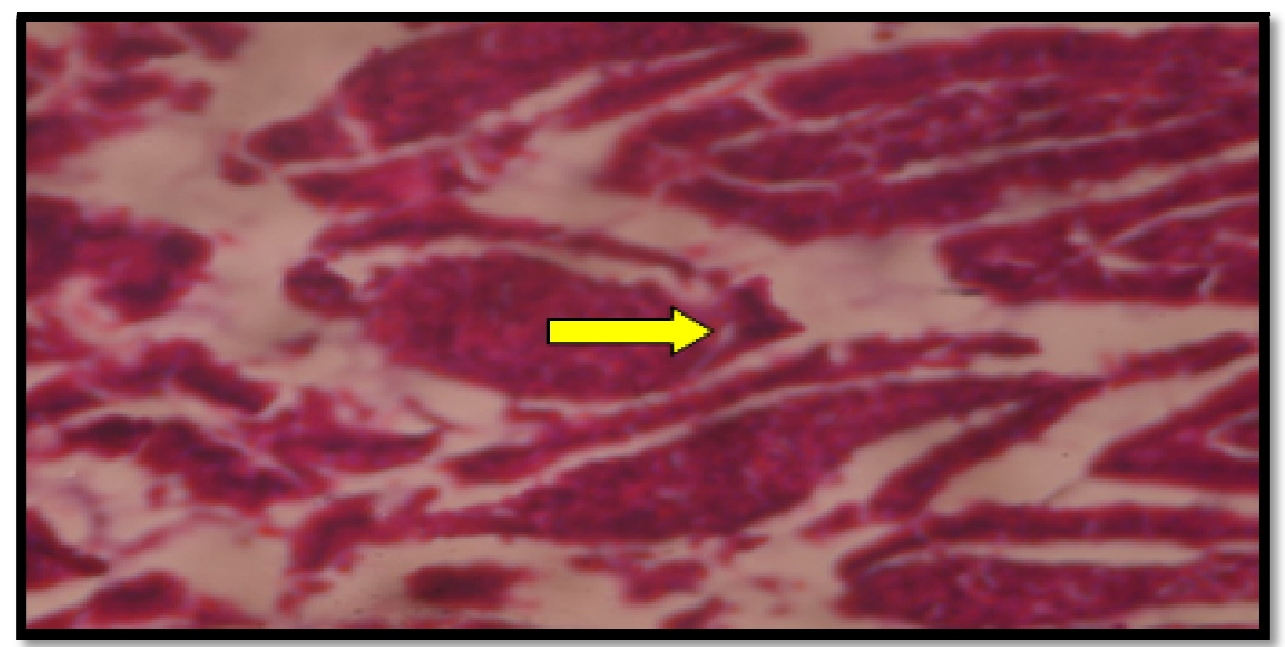

Figure 15: Photomicrograph of The Small Intestine of Rat Infected with S. Typhi and Treated with 500mg/ Kg of Ciprofloxacin for 10 Days, Showing Small Intestine Villus with columnar Epithelium, No Pathologies Were Seen 


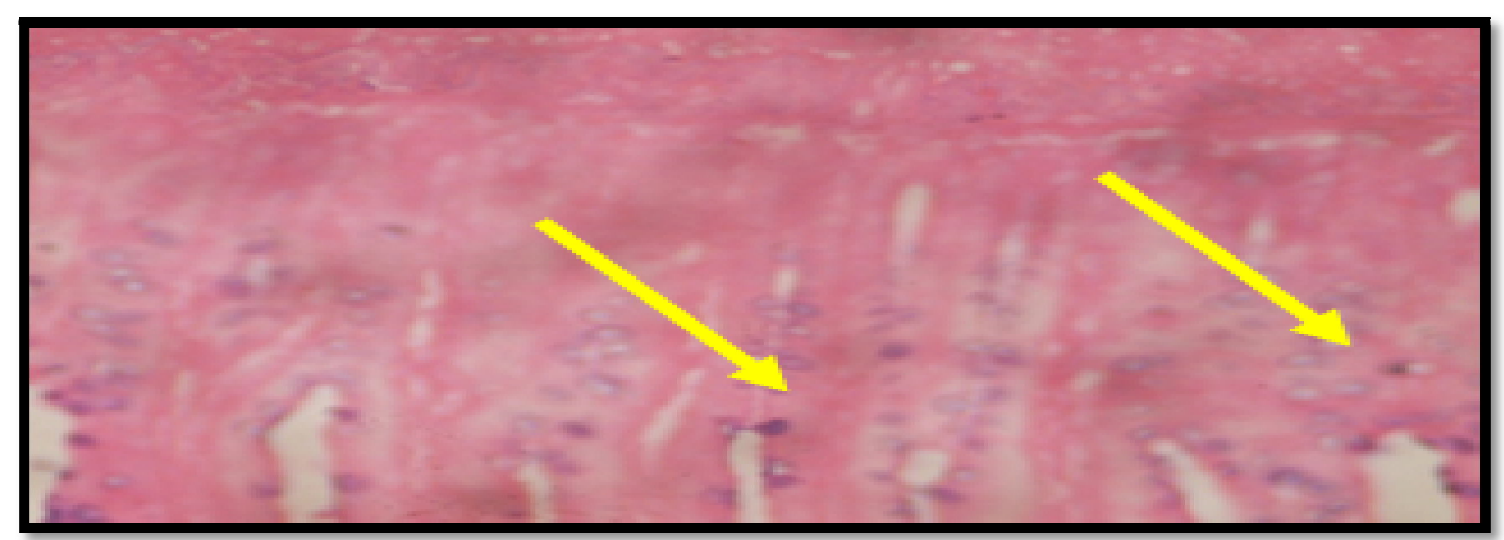

Figure 16: Photomicrograph of the Small Intestine of Rat Infected with S. Typhi and Treated with $100 \mathrm{mg} / \mathrm{Kg}$ of C. Odorata for 15 Days Showing Disruption of Tissues

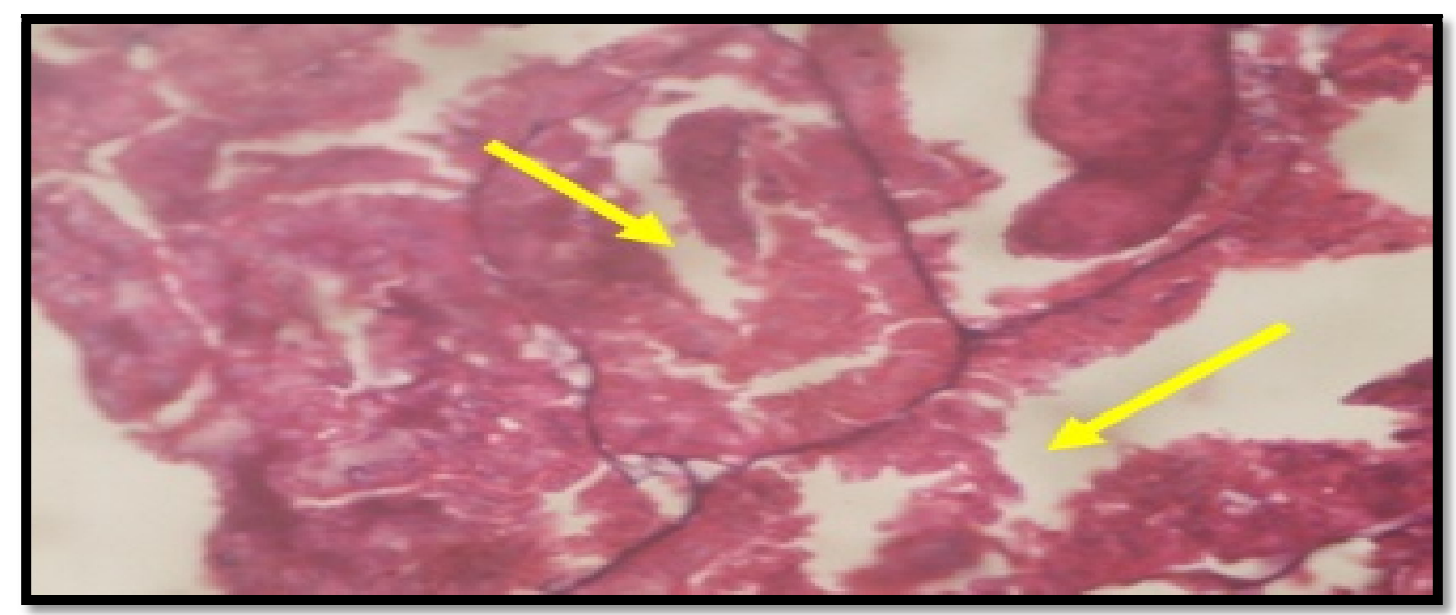

Figure 17: Photomicrograph of the Small Intestine of Rat Infected with S. Typhi and Treated with 200mg/ Kg of C. Odorata for 15 Days, Showing Normal Tissue Architecture

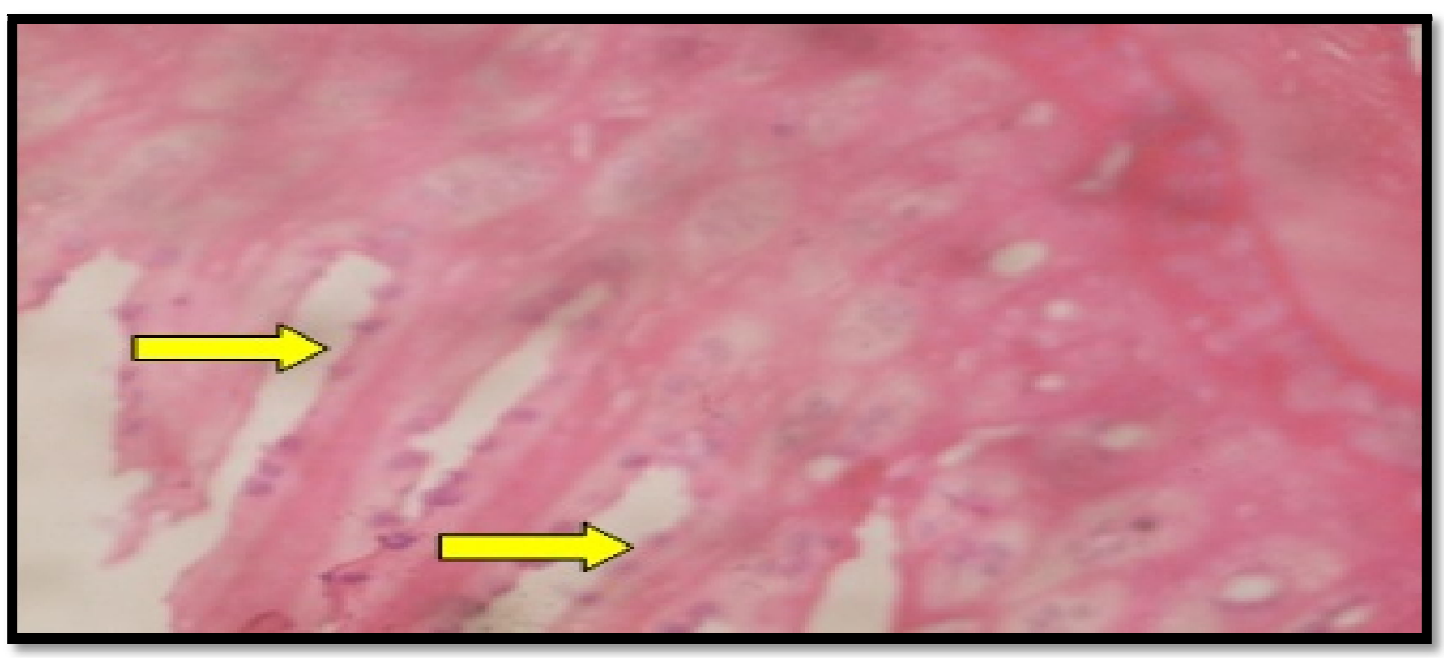

Figure 18: Photomicrograph of the Small Intestine of Rat Infected with S. Typhi and Treated with $400 \mathrm{mg} / \mathrm{Kg}$ of C. Odorata for 15 Days Showing Normal Tissue Architecture

\section{Discussion}

Increased triacylglycerol levels as well as increase in VLDL and reduced HDL cholesterol levels are characteristic changes that have been reported to occur during infection (Grunfeld, et al., 1992 and Sammalkorpi, et al., 1988). According to Tiirola, et al., (2007) and Nonogaki, et al., (1995), elevation of plasma triacylglycerol level could be the result of either increased VLDL production or decreased VLDL clearance. Nonogaki, et al., (1995) and Hardardottir, et al., (1997) have remarked that experiments in rats and mice showed that even at low doses, bacteria lipopolysaccharide (LPS) can rapidly 
stimulate VLDL production by increasing adipose tissue lipolysis, increasing hepatic de novo fatty acid synthesis, and decreasing hepatic fatty acid oxidation, which he said, these changes provide fatty acid substrate for esterification into triacylglycerols and assembly into VLDL particles in the liver. Yet in another account, Xu, \& Nilsson, (1996) remarked that injection of bacteria or LPS into rats had been reported to significantly inhibit the clearance of LDL from the circulation while Wright, et al., (1997) and Sakaguchi, \& Sakaguchi, (1979) associated this effect to be responsible for the marked increase VLDL-triacylglycerol.Finally, Solomon et al., (2012), concluded that this mechanism may also have been responsible for the increased plasma and erythrocyte free fatty acids observed in the experimental rats infected with Salmonella as the increase in free fatty acids was associated with increased LDL-VLDL and plasma triacylglycerols. To corroborate these findings, Solomon, et al., (2012) reported an increase in triacylglycerol levels as well as increase in VLDL and reduced HDL cholesterol levels in Wistar rats infected with Salmonella typhi bacteria.Studies on the hypo-glycemic effects of ethanol leaf extract of Chromolaena odorata carried out by Ijeoma, et al., (2014), revealed that this plant extract significantly reduces the serum total cholesterol, LDL-cholestorol and triacylglycerol and significantly increase HDL-cholesterol, depicting a hypo-lipidaemic, as well as cardioprotective effect of the extract against degenerative diseases. This according to a report by Nwanjo, et al., (2007), was attributed it to the presence of saponin fractions. Other studies have also remarked that the lowering of blood cholesterol is associated with the presence of saponins and flavonoids (Ikeyi, et al., 2013) which are reported to be found in Chromolaena odorata extract (Prasad, et al., 2005). In our study it was observed that pre-treatment of albino rats with Chromolaena odorata caused a significant and dose dependent increase in High Density Lipoprotein Cholesterol (HDL) and a decrease in Low Density Lipoprotein Cholesterol [LDL, Triglycerides and Cholesterol. These findings agree with studies on the hypo-glycemic effects of ethanol leaf extract of Chromolaena odorata carried out by Ijioma et al., (2014), but inoculation subsequent to pretreatment of animals with Salmonella typhi caused a slight increase in the levels of cholesterol, LDL-cholestorol and triacylZglycerol and a decrease in the levels of HDL-cholesterol which were not significantly different from the normal, thus indicating that the plant has a preventive dys-lipidermic effect against Salmonella typhi infection. The inhibition of the dyslipidemia may also be the result of suppressive effect against the bacterial growth. This could be considered as an antisalmonella effect as has been reported by Lovet \& Douye, (2013).

Histological examination of the section of small intestine of normal control group showed normal epithelial lining that is typically of the columnar variety, while those of the infected group showed intensely disrupted tissues which agree with the report of Zainab (2012) who reported tissue hyperplasia and infiltration well as degeneration of the brush border and the apical cytoplasm. Treatment with the extracts reversed these pathological changes. This may be due to eradication of the bacteria from the gastro-intestinal tract of the animals, followed by healing of the tissues. Thus, this is an evidence of antisalmonella typhiproperty of this extract.

\section{Conclusion}

Pre-treatment of albino rats with Chromolaena odorata caused increase in High Density Lipoprotein Cholesterol (HDL) and a decrease in Low Density Lipoprotein Cholesterol (LDL), Triglycerides and Cholesterolm while subsequent inoculation resulted in a slight insignificant increase in the levels of cholesterol, LDL-cholestorol and triacylglycerol and a slight decrease in the levels of HDL-cholesterol. Salmonellatyphi infection caused disruption to perforation of small intestines tissues, while treatment resulted in a dose dependent reversal effect ranging from infection of villi, to sloughing of the lining and poorly organized villi as well as proliferation of gut associated lymphatic tissue to restoration of normalcy to intestinal tissue architecture.

\section{References}

i. Baker, J. R. (1945). Cytological Technique. (2nd ed.), (p. 211). London: Methuen.

ii. Grunfeld, C., Pang, M., Doerrler, W., Shigenaga, J. K., Jensen, P., Feingold, K. R. (1992): Lipids, lipoproteins, triglyceride clearance, and cytokines in human immunodeficiency virus infection and the acquired immunodeficiency syndrome.J Clin Endocrinol Metab, 74, 1045-1052.

iii. Hanan, B., Akram, H., Hassan, R, Ali, H., Zeinab, S., \& Bassam, B. (2013). Techniques for the Extraction of Bioactive Compounds from Lebanese Urtica dioica. Maceration method. American Journal of Phytomedicine and Clinical Therapeutics, 1(6), 507-513

iv. Hardardottir, I., Sipe, J., Moser, A. H., Fielding, C. J., Feingold, K. R., \& Grunfeld, C. (1997) LPS and cytokines regulate extra hepatic mRNA levels of apolipoproteins during the acute phase response in Syrian hamsters. Biochim Biophys Acta, 1344, 210-220.

v. Ijeoma, S. N., Okafor, A. I., Ndukuba, P. I., Nwankwo, A. A., \& Akomas, S. C. (2014). Hypoglycemic, hematologic and lipid profile effects of Chromollena odorata ethanol leaf in alloxan induced diabetic rats. Annals of Biological Sciences, (3), 27-32.

vi. Ikeyi, A. P., Ogbonna, A. O., Inain, D. E., \& Ike, A. O., (2013). Phytochemical analysis of Pineapple Fruit (Ananascomosus) and Fluted Pumpkin Leaves (Telfaira occidental). World Journal of Pharmaceutical Research, 2 (4), 712-719.

vii. Lothar, Thomas ed. TH Books (1998). Use and Assessment of Clinical Laboratory results. Clinical Laboratory Diagnosis. (1 ${ }^{\text {st }}$ Edition), Verlagsgesellschaft mbH Frankfurt/ Main, Gemany, P, 169. 
viii. Lovet, T. K., \& Douye, V. Z. (2013). Activity of Chromolaena odorata on enteric and superficial etiologic bacterial agents. American Journal of Research Communication. 1(11): 266-278.

ix. Nonogaki, K., Moser, A. H., Pan, X. M., Staprans, I., Grunfeld, C., \& Feingold, K. R. (1995) Lipoteichoic acid stimulates lipolysis and hepatic triglyceride secretion in rats in vivo.J Lipid Res, 36, 1987-1995.

x. Nwanjo, H. U., Oze, G., Okafor, M. C., Nwosu, D., \& Nwankpa, P. (2007). Protective role of Phyllantus niruri extract on serum lipid profiles and oxidative stress in hepatocytes of diabetic rats. African Journal of Biotechnology, 6, 17441749.

xi. Ogbonnia, S. O., Mbaka, G. O., Anyika, E. N., Osegbo, O. M., \& Igbokwe, N. H. (2010). Evaluation of acute toxicity in mice and subchronic toxicity of hydroethanolic extract of Chromolaena odorata (L.) King and Robinson (Fam. Asteraceae) in rats, Agric. Biol. J. N. Am., 1(5), 859-865.

xii. Omeh, Y. N., Ejiofor, U. E., Echeme, A. M., \& Nwoko O. C. (2015). Evaluation of the Serum Liver Enzymes Markers, Lipid Profile and Kidney Function Parameters inTyphoid Patients. International Journal of Tropical Disease and Healt, 8(2), 79-89.

xiii. Prasad, S., Narayana, J., Jayakumar, K., \& Srikanth, K. C. (2005). Phytochemical analysis of toxic plants Chromollena odorata. Journal of Indian Society of Toxicology,1 (1), 17-19

xiv. Sakaguchi, O, \& Sakaguchi S. (1979). Alterations of lipid metabolism in mice injected with endotoxin. Microbiol Immunol, 23:71-85.

xv. Sammalkorpi, K., Valtonen, V., Kerttula, Y., Nikkila, E., \& Taskinen, M. R. (1988). Changes in serum lipoprotein pattern induced by acute infections. Metabolism 1988, 37:859-865.

xvi. Solomon, O. R., David, A. O., Olusola, A. T., Elizabeth, A. B., \& Oladipo, A. (2012). Tissue dyslipidemia in salmonellainfected ratstreated with amoxillin and pefloxacin. Lipids in Health and Disease, 11 (152), 1-11.

xvii. Tietz, N. W. (1995). Clinical Guide to Laboratory Tests. (3rd Edition), WB Saunders Company Philadelphia P.A pp 518519.

xviii. Tiirola, T., Jauhiainen, M., Erkkila, L., Bloigu, A., Leinonen, M., Haasio, K., Laitinen, K., Saikku, P. (2007). Effect of pravastatin treatment on Chlamydia pneumonia infection, inflammation and serum lipids in NIH/S mice. Int J Antimicrob Agents, 29, 741-742.

xix. Watson, K. C. (1954). Clot culture in typhoid fever.J Clin Pathol, 7, 305-307.

xx. Watson, K. C. (1978). Laboratory and clinical investigation of recovery of Salmonella typhi from blood.J Clin Microbiol 7, 122-126.

xxi. Wright, L. C., Nouri-Sorkhabi, M. H., May, G. L., Danckwerts, L. S., Kuchel, P. W., Sorrell, T. C. (1997). Changes in cellular and plasma membrane phospholipid composition after lipopolysaccharide stimulation of human neutrophils, studied by 31P NMR. Eur. J. Biochem., 15, 243 (1-2), 328-35

xxii. Xu, N., \& Nilsson, A. (1996). Endotoxin inhibits catabolism of low density lipoproteins in vivo: an experimental study in the rat. Scand J Clin Lab Invest 1996, 56:53-61.

xxiii. Zainab, R. Z. (2012). Histopathological study of Salmonella typhimurium infection inlaboratory mice by using the light and electron microscope. Kufa Journal for Veterinary Medical Sciences. 3 (1), 1-8. 